\title{
Labour Market Performance in EU Member States: A Panel Regression Approach
}

\author{
Michal Tvrdon
}

\begin{abstract}
This paper deals with labour market institutions and their influence on labour market performance in the $\mathbf{E U}$ Member States. We perform an econometric analysis to estimating the impact of various institutional aspects on the employment rate, the unemployment rate and the long-term unemployment rate. Our econometric analysis suggests that two institutional factors significantly influence unemployment and long-term unemployment: total tax wedge on labour and active labor market policies. While higher tax burden significantly increases the unemployment rate, active labor market policies work in the opposite direction and may offset the negative effect of high taxation of labour.
\end{abstract}

Index Terms-Employment protection legislation, employment, labour taxation, panel regression, unemployment, wage bargaining.

\section{INTRODUCTION}

There have been published many studies whose main aim was to find if there is a relationship between the setting of the labour market institutions and the level of unemployment or employment; or in other words, if these institutional aspects can have impacts on the unemployment rate or rather the employment rate. Some recent studies have also focused on a wider analysis of labour market institutions - e.g. they concentrated on the influence of these aspects on the business cycle, on the volatility of output, business environment, inflation or corruption [1]. The paper deals with main findings and conclusions of the most important studies in this research area.

The paper is structured as follows: 1) in the first part, we focus on review of literature and comparison of main findings from previous studies; 2) in the second part, we define the concept of panel regression; 3 ) in the next part, we present empirical results and the last one concludes.

\section{REVIEW OF LITERATURE}

One of the key works in this field is the study of Nickell [2]. He examined the relationship between unemployment expressed by the logarithm of the unemployment rate and labour market institutions in 20 OECD countries from 1983 to 1988 and from 1989 to 1994 . Performed regression analysis did not show the influence of employment protection legislation on unemployment (coefficients were only slight or entirely insignificant). Conversely, Nickell [2] demonstrated

Manuscript received July 15, 2013; revised November 8, 2013.

Michal Tvrdon is with the Silesian University in Opava, School of Business Administration, Univerzitni nam. 1934/3, 73340 Karvina, Czech Republic (e-mail: tvrdon@ opf.slu.cz). a negative correlation between EPL and the employment rate. In the case of unemployment benefits, expressed by the gross replacement rate, computed coefficient suggested the strong influence of this aspect on the unemployment rate. If a generous system of unemployment benefits increases the unemployment rate, active labour market policy measures seem to be a compensating factor that, according to results of this analysis, reduces long-term unemployment. In the case of collective bargaining Nickell [2] distinguishes density of trade unions and co-ordination of wage bargaining (for more on these concepts see Tvrdon [3]. Existence of legislation extending the results of collective bargaining on employers or sectors that are not participating in this process has an impact on unemployment in terms of its increase. Adverse effects of high rate of trade unions'coverage can be mitigated if wage bargaining is coordinated.

Another high cited work is the paper of Blanchard and Wolfers [4]. Author investigated the role of shocks and labour market institutions in increasing the unemployment rate in Western Europe countries. Correlation coefficients indicated that higher replacement rate, a longer period of provided unemployment benefits, stricter employment protection legislation, higher taxes on labour, higher density and higher trade unions' coverage lead to greater effects of shocks on unemployment. On the contrary, active labour market policies and coordination of wage bargaining mitigated impacts of supply or demand shocks on the labour market.

Belot and van Ours [5] performed panel data regression analysis. Panel data consists of 18 OECD countries from 1960 to 1994. Estimated correlation coefficients led the authors to conclusion that the unemployment rate is positively influenced by labour taxation and unemployment benefits and trade unions'density. On the contrary, strict EPL and high centralization of collective bargaining influenced the unemployment rate in reverse direction.

Bassanini and Duval [6] were interested in the impact of structural policies and institutions on the aggregate unemployment rate, respectively the employment rate. Although the main goal to thein paper is to estimate the impact of institutional aspects on the above mentioned variables, value added of this paper can be seen in defining the role of market regulation. According to them almost two-thirds of non-cyclical unemployment changes can be explained by changes in government policy and labour market institutions. Moreover, high and long-term provided unemployment benefits are among factors that could increase the aggregate unemployment rate. Another factors with the same impacts are high taxes and strict labour market regulation that does not support competition. Conversely, 
lower unemployment can be reached if there exists combination of highly centralized or coordinated wage bargaining and some active labour market policy measures. According to authors' estimations employment protection legislation did not have significant effect on aggregate unemployment.

Fialová and Schneider [7] examined effects of institutional aspects on the unemployment rate, the long-term unemployment rate, the employment rate and the economic activity rate using the panel regression (year 1999 and 2004). The authors found out high taxation of labour and strict EPL tend to increase unemployment and tend to reduce economic activity. However, active labour market policiy measures tend to reduce unemployment and tend to increase the economic activity rate. A similar effect was also observed in coverage of collective bargaining. Although the significance of this effect seems to be low.

Lehman and Muravyev [8] focused their attention on the transition countries. Contrary to previous studies, dependent variables included the unemployment rate of graduates. To determine whether the institutional aspects influence the unemployment rate of graduates is particularly important today, when many European countries have to face a new phenomenon - a high number of unemployed graduates (most frequently mentioned example is Spain with the unemployment rate of graduates approaching nearly $50 \%$ ). Performed regression analysis confirmed the conclusions mentioned in Scarpetta [9] - strict EPL significantly increases the unemployment rate of graduates. Conversely, higher expenditure on active labour market policies reduces unemployment of graduates. In the case of effects of active labour market policies and EPL on other dependent variables (the total unemployment rate, the long-term unemployment rate and the employment rate) authors confirmed findings from previous studies. Moreover, insignificant effects of union density, unemployment benefits and tax wedge were found.

From the recent studies we can mention the paper of Rottmann and Flaig [10]. The authors conducted a panel regression on data from 19 OECD countries from 1960 to 2000. Their findings were similar to previous studies - it means that strict EPL, high tax wedge and a generous system of unemployment benefits increase unemployment. Conversely, higher degree of centralization of wage bargaining reduces unemployment. However, the strength of these effects varies considerably among countries.

Present studies focus on other relationships. For example Potrafke [11] concentrated on the potential relationship between labour market institutions and globalization. The analysis is based on data from 20 OECD countries between the years 1982 and 2003. The author concluded that globalization does not affect the replacement rate, the duration of unemployment benefits, public spending on active labour market policies, taxation of labour and labour market regulation. In the case of standard employment contracts regulation, globalization has reduced stringency of regulation. The author also believes that the labour market institutions are influenced rather by government policy than globalization itself.

An alternative view offers Rumler and Scharler [12]. They studied the effects of labour market institutions on macroeconomic volatility on the example of 20 OECD countries. The analysis showed that countries with high union density are more exposed to volatile changes in output, while the degree of coordination of wage bargaining and EPL strictness have little effect on output volatility. Another conclusion is that highly coordinated wage bargaining has a dampening effect on inflation volatility.

The latter relationship is closely connected with the research conducted Abbrittem and Weber [13], which examined institutional aspects and their impacts on the dynamics of inflation and unemployment. According to the authors labour market institutions can be divided into two groups: 1) those that cause rigidity of unemployment; and 2) those that cause real wage rigidity. This division is important because labour market institutions should be seen individually, as their effects on the economic cycle are different and their interaction is a key factor in the dynamics of inflation and unemployment.

\section{MeThODOLOGY}

In order to explain the characteristics of the labour market institutions and the dependent variables in the EU Member States, we apply simple descriptive statistics. We conducted panel data regression analysis. Panel data estimation is often considered to be an efficient analytical method in handling econometric data. According to Asteriou and Hall [14] panel data estimation can offer some considerable advantages: (1) the sample size can be increased considerably by using a panel and hence much better estimates can be obtained; (2) under certain circumstances the problem of omitted variables which might cause biased estimates in a single individual regression may not occur in a panel context.

A panel data set is formulated by a sample that contains $N$ cross-sectional units that are observed at different $T$ time periods. Consider for example a simple linear model with one explanatory variable as given by:

$$
Y_{i t}=\alpha+\beta X_{i t}+\varepsilon_{i t}
$$

where the variables $Y$ and $X$ have both $i$ and $t$ subscripts for $i$ $=1,2 \ldots N$ sections and $t=1,2 \ldots T$ time periods. If our sample set consist of a constant $\mathrm{T}$ for all cross-sectional units, or in other words if we obtain a full nest of data both across countries and across time, then the data set is called balanced. Otherwise when observations are missing for the time periods of some of the cross-sectional units the panel is called unbalanced. If we have different countries in our sample, we can expect differences in their behavior. Thus our model can be formally written as:

$$
Y_{i t}=\alpha+\beta_{1} X_{1 i t}+\beta_{2} X_{2 i t}+\ldots+\beta_{k} X_{k i t}+\varepsilon_{i t}
$$

where $Y_{i t}$ depends on a set of $K$ explanatory variables $X_{i t}$ and the constants are specific to the $i$-th unit (country) at time $t$, at the same time but are constant.

In this paper, we used three different methods: 1) the common constant model; 2) the fixed effects model and 3) the random effects model. 
1) The Constant Coefficients Model (also called the pooled OLS model) is the type of panel model that has constant coefficients, referring to both intercepts and slopes. In the event that there is neither significant country nor significant temporal effects, we could pool all of the data and run an ordinary least squares regression model. Although most of the time there are either country or temporal effects, there are occasions when neither of these is statistically significant.

2) The Fixed Effects Model (FEM) is another type of panel model that would have constant slopes but intercepts that differ according to the cross-sectional (group) unit-for example, the country. Although there are no significant temporal effects, there are significant differences among countries in this type of model. While the intercept is cross-section (group) specific and in this case differs from country to country, it may or may not differ over time. This model can be written Asteriou and Hall [14]:

$$
Y_{i t}=\alpha_{i}+\beta_{1} X_{1 i t}+\beta_{2} X_{2 i t}+\ldots+\beta_{k} X_{k i t}+\varepsilon_{i t}
$$

The fixed effect model is a very useful basic model to start from; however, traditionally, panel data estimation has been mainly applied to datasets where $N$ is very large and in this case a simplifying assumption is sometimes made which gives rise to the random effects model.

3) The Random Effects Model (REM) is also called a regression with a random constant term. One way to handle the ignorance or error is to assume that the intercept is a random outcome variable. The random outcome is a function of a mean value plus a random error. But this cross-sectional specific error term vi, which indicates the deviation from the constant of the cross-sectional unit (in this example, country) must be uncorrelated with the errors of the variables if this is to be modeled. The time series cross-sectional regression model is one with an intercept that is a random effect.

4) Hence, the variability of the constant for each section comes from the fact that:

$$
\alpha_{i}=\alpha+v_{i}
$$

The regression equations have following forms:

$$
\begin{gathered}
Y_{i t}=\left(\alpha+v_{i}\right)+\beta_{1} X_{1 i t}+\beta_{2} X_{2 i t}+\ldots+\beta_{k} X_{k i t}+\varepsilon_{i t} \\
Y_{i t}=\alpha+\beta_{1} X_{1 i t}+\beta_{2} X_{2 i t}+\ldots+\beta_{k} X_{k i t}+\left(v_{i}+\varepsilon_{i t}\right) \\
U R_{i t}=\alpha_{i}+\beta_{1} E P L_{i t}+\beta_{2} C O V_{i t}+ \\
\beta_{3} A L M P_{i t}+\beta_{4} T A X_{i t}+\beta_{5} N R R_{i t}+\varepsilon_{i t} \\
L U R_{i t}=\alpha_{i}+\beta_{1} E P L_{i t}+\beta_{2} C O V_{i t}+ \\
\beta_{3} A L M P_{i t}+\beta_{4} T A X_{i t}+\beta_{5} N R R_{i t}+\varepsilon_{i t} \\
E R_{i t}=\alpha_{i}+\beta_{1} E P L_{i t}+\beta_{2} C O V_{i t}+ \\
\beta_{3} A L M P_{i t}+\beta_{4} T A X_{i t}+\beta_{5} N R R_{i t}+\varepsilon_{i t}
\end{gathered}
$$

where $v_{i}$ is a zero mean standard random variable.

The random effects model therefore takes the following form (Asteriu and Hall [14]):
Given a model and data in which fixed effects estimation would be appropriate, a Hausman test tests whether random effects estimation would be almost as good. In a fixed-effects kind of case, the Hausman test is a test of H0: that random effect would be consistent and efficient, versus H1: that random effect would be inconsistent. The result of the test is a vector of dimension $\mathrm{k}$ ( $\operatorname{dim}(b)$ ) which will be distributed chi-square $(k)$. So if the Hausman test statistic is large, one must use FE. If the statistic is small, one may get away with RE.

According to Gujarati and Porter [15] if it is assumed that and the $X^{\prime} \mathrm{s}$ are uncorrelated, REM may be appropriate, whereas if and the $X^{\prime}$ s are correlated, FEM may be appropriate.

In the next part of this section, we provide empirical results which were obtained from EView 7.

\section{EMPIRICAL RESULTS}

In this chapter of the paper, we present estimates of institutional aspects' impacts (as independent variables) on individual labour market macroeconomic indicators (dependent variables) - the employment rate, the unemployment rate and the long-term unemployment rate. We constructed a panel of 15 EU Member States (11 Eurozone Member States and four Visegrad Group countries) and used data from years 2000 till 2008.

As mentioned above, we set the unemployment rate (UR), the long-term unemployment rate (LUR) and the employment rate (ER) as dependent variable $Y_{i t}$. We set eployment protection legislation (EPL), collective bargaing coverace (COV), taxation of labour (TAX), initial net replacement rate (NRR) and active labour market policies (ALMP) as explanatory variables $X_{i t}$ (see Table I).

TABLE I: CHARACTERISTIC OF VARIABLES IN MODEL

\begin{tabular}{|l|l|l|l|l|l|l|}
\hline $\begin{array}{l}\text { Dependent } \\
\text { variable }\end{array}$ & Code & Source & $\begin{array}{l}\text { Explaining } \\
\text { variable }\end{array}$ & Code & Units & Source \\
\hline $\begin{array}{l}\text { Unemployment } \\
\text { rate }\end{array}$ & UR & Eurostat & $\begin{array}{l}\text { Employment } \\
\text { protection } \\
\text { legislation }\end{array}$ & EPL & $\begin{array}{l}\text { indice 0-6 (the } \\
\text { higher value the } \\
\text { more stringent) }\end{array}$ & OECD \\
\hline $\begin{array}{l}\text { Long-term } \\
\text { unemployment }\end{array}$ & LUR & Eurostat & $\begin{array}{l}\text { Collective } \\
\text { bargaining } \\
\text { coverage }\end{array}$ & COV & $\begin{array}{l}\text { (as \%, shows the } \\
\text { percentage of } \\
\text { labor force) }\end{array}$ & ICTWSS \\
\hline Employment & ER & Eurostat & Labor taxation & TAX & $\begin{array}{l}\text { (as \% of total } \\
\text { labor costs - sum } \\
\text { of income tax and } \\
\text { employee and } \\
\text { employer social } \\
\text { security } \\
\text { contributions) }\end{array}$ & OECD \\
\hline & & & & $\begin{array}{l}\text { (as \%, the fraction } \\
\text { of current } \\
\text { or potential } \\
\text { income which the } \\
\text { social system } \\
\text { provides } \\
\text { to a person if he or } \\
\text { she does not work) }\end{array}$ & OECD \\
\hline & & & $\begin{array}{l}\text { Active labor } \\
\text { market policies }\end{array}$ & ALMP & $\begin{array}{l}\text { (expenditures as } \\
\text { \% of GDP) }\end{array}$ & Eurostat \\
\hline
\end{tabular}

Source: own processing

A following Table II shows results of panel regression. We used lest squares estimation procedure. Firstly, we estimated parameters in the model, where the unemployment rate was a dependent variable. Estimated regression coefficients indicate positive impact of EPL, COV, TAX and NRR on the unemployment rate. In other words, with the increase of 
explanatory variables increases also a dependent variable. The model seems to be statistically significant. Regression coefficients estimation was performed at a significance level of $5 \%$. However, EPL and NRR were statistically insignificant. According to an estimated regression coefficient ALMP had the highest influence on UR. The negative value of the coefficient indicates that if ALMP expenditures increase, UR decreases significantly.

\begin{tabular}{|l|r|r|r|}
\multicolumn{1}{l|}{ TABLE II: RESULTS OF REGRESSION ANALYSIS } \\
\hline & & & \\
& $\begin{array}{l}\text { Unemeloyment rate } \\
\text { UR }\end{array}$ & $\begin{array}{l}\text { Long-term } \\
\text { unemployment LUR }\end{array}$ & Employment rate ER \\
\hline constanta & $-19,44942$ & $-12,73346$ & 100,2585 \\
\hline EPL & 0,855097 & 0,418003 & $-2,32178$ \\
\hline COV & 0,135807 & 0,092229 & $-0,287875$ \\
\hline ALMP & $-3,43786$ & $-2,198653$ & $-2,195629$ \\
\hline TAX & 0,414745 & 0,231966 & $-0,231564$ \\
\hline NRR & 0,016285 & 0,01319 & $-0,007662$ \\
\hline $\begin{array}{l}\text { N (country, } \\
\text { time) }\end{array}$ & $135(15,9)$ & $135(15,9)$ & $135(15,9)$ \\
\hline
\end{tabular}

Source: own calculation

In the case of the long-term unemployment we have come to similar findings - ALMP a TAX have effect on the long-term unemployment. However, these effects are moderate in comparison with the effects of these variables on the unemployment rate. Moreover, regression EPL and NRR coefficients seem to be statistically insignifant.

In the last model, where we used the employment rate as a dependent variable gives us different results. As statistically insignifant were variables NRR and ALMP. Other explanatory variables have negative effects on the employment rate. The highest effect showed EPL.

\section{CONCLUSION}

Our econometric analysis suggests that two institutional factors significantly influence unemployment and long-term unemployment: total tax wedge on labour and active labour market policies. While higher tax burden significantly increases the unemployment rate, active labour market policies work in the opposite direction and may offset the negative effect of taxation. Panel regression showed that a relatively significant impact on employment rate has employment protection legislation. In other words, stricter EPL causes a decrease in the employment rate. As in the previous case, results showed a very weak influence of collective bargaining on the employment rate. Other variables appeared to be statistically insignificant.

We can say that our results confirmed conclusions from previous studies. They showed that effect of labour market institutions on these variables is ambiguous. This is largely due to the specifics of the labour market that differs from other markets in the economy considerably.

\section{REFERENCES}

[1] I. Kotlan and E. Kotlanova, "The influence of the institutional factors on the corruption: the empirical analysis," Politicka Ekonomie, vol. 60, issue 2, pp. 167-186, 2012

[2] S, Nickell, L. Nunziata, W. Ochel, and G. Quintini, The Beveridge Curve, Unemployment and Wages in the OECD from 1960s to the 1990s, London: Centre for Economic Performance, London School of Economics and Political Science, 2001.

[3] M. Tvrdon, "Institucionální aspekty fungování trhu práce (institutional aspects of labour market)," Politicka Ekonomie, vol. 56, issue 5, pp. 621-642, 2008.

[4] O. Blanchard and J. Wolfers, "The Role of Shocks and Institutions in the Rise of European Unemployment: The Aggregate Evidence," Working Paper, no. 7282, Cambridge (MA): NBER, 1999.

[5] M. Belot and J. C. V. Ours, "Unemployment and labor market institutions: an empirical analysis," Journal of the Japanese and International Economies, vol. 15, pp. 403-418, 2001.

[6] A. Bassanini and R. Duval, "Employment Patterns in OECD Countries: Reassesing the Role of Policies and Institutions," OECD Economics Department Working Papers, no. 486, 2006.

[7] K. Fialová and O. Schneider, "Labour Market Institutions and Their Contribution to Labour Market Performance in the New EU Member Countries," IES Working Paper 27, 2007.

[8] H. Lehmann and A. Muravyev, "How Important Are Labor Market Institutions for Labor Market Performance in Transition Countries?" IZA Discussion Paper, no. 4673, 2009.

[9] S. Scarpetta, "Assessing the Role of Labour Market Policies and Institutional Settings on Unemployment: A Cross-Country Study," Economic Studies, no. 26, Paris: OECD, 1996.

[10] H. Rottmann and G. Flaigh, Labour Market Institutions and Unemployment: An International Comparison, HAW im Dialog Weidener Diskussionpapiere, no. 31, 2001.

[11] N. Potrafke, "Labor market deregulation and globalization: empirical evidence from OECD countries," Review of World Economics, vol. 146, issue 3, pp. 545-571, 2010.

[12] F. Rumler and J. Schlarler, "Labor Market Institutions and Macroeconomic Volatility in a Panel of OECD Countries," European Central Bank Working Paper Series, no. 1005, 2009.

[13] M. Abbiritt and S. Weber, "Labor Market Institutions and the Business Cycle: Unemployment Rigidities vs. Real Rigidities," European Central Bank Working Paper Series, no. 1183.

[14] D. Asteriou and S. G. Hall, Applied Econometrics, Palgrave Mac Millan, New York, 2007.

[15] D. Gujarati and D. C. Porter, Basic Econometrics, 5th ed. Mc Graw-Hill, Boston, 2009.

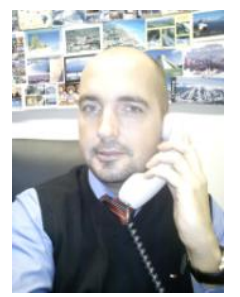

M. Tvrdon was born at Hranice in the Czech Republic on August 24, 1978. He received his BSc degree in Economics at the Silesian University in Opava, in 2000; MS in Economics at the same university, in 2003. After one year work experience, he registered at the Masaryk University in Brno in the Czech Republic for a Ph.D. in Economic policy. He completed the doctoral research and defended his doctoral thesis (Institutional framework of labor market performance: the case of the Czech Republic) in 2007. Currently he works as a full-time Assistant Professor at the Silesian University, School of Business Administration, Czech Republic. His research interests are related to labor economics, European integration and regional disparities. He has published several research papers and appeared in international journals and ISI conference proceedings. 